\title{
Relevance of Shakespearean poetry and drama to the present Indian scenario
}

\author{
Amir Hossain Khan
}

Asst. Professor, Balarampur College, Purulia, West Bengal, India

amirhossainkhan.english@gmail.com

\begin{abstract}
Literature is the mirror of the society. Time changes and world with its different pockets change shapes with passage of time, but the fundamental elements of Nature remain always the same. It is also true that great people of the world think always the same. What a great thinker thought long ago may be matched with the idea of another thinker much later. Besides, great authors are philosophers capable of seeing into the heart of the future. Shakespeare was such a visionary. What he thought three centuries ago and used as the materials of his dramas - both tragedies and comedies as also histories and sonnets - may now be seen happening in countries all over the world not excluding India. India, which now is a democratic country, after more than seven decades of her independence has much common with the countries in Europe, the basis of Shakespeare's dramatic art. Political murders in line with Macbeth's assassination of King Duncan and that of Banquo by mercenaries employed by Macbeth have their reflections in many political murders taking place almost everyday in India. But the plethora of crime cannot retard the flowering of the sweeter emotions like kindness, love, and charity. Even today there are many people, the Christian saints like Mother Theresa, the Buddhist and Hindu monks who employ their all energy for the purgation of the rotten human society. With the seven deadly sins running in the society there is also the strong undercurrent of love and forgiveness. In Shakespeare's 'The Merchant of Venice', Portia, disguised as a male law-clerk, delivered a rich and long lecture on the quality of mercy in order to make change of Shylock's heart, but she succeeded when she blended her legal acumen with a measure of witty tricks. This mixture may worsen the quality of truth and may bring some instant gain, but an unmixed truth is always victorious. Shakespeare propounded this victory of religion over villainy and it is what happens in the present Indian situation.
\end{abstract}

Keywords-Age, Comedy, Democracy, India, Murder, Politics, Tragedy.

\section{INTRODUCTION}

It is almost four centuries since Shakespeare lived and wrote in the closing years of the $16^{\text {th }}$ century and those of the early years of the next, but the relevance of the same does not appear to have faded with the passage of so many years. Rather, it has increased with the growing time so much so that we today notice the relevance of the greatest poet and dramatist in almost in every field of national life. Every play and every sonnet has grown in its respective field very rapidly and those who go deep into the root of the thoughts concerned can realise the potency of the ideas contained in the works. It is true that monarchy has long ago ceased toexist and it has been replaced by democracy, yet the original idea matches with any concept with which it is compared.

\section{DISCUSSION}

We may take up a singular play called the 'As You Like It' which is set in France in Europe away from the Asian soil, but even today the original themes are as liable to be superimposed to the current activities of the humanity as it was at that time in that country so many centuries ago. The themes of love, rivalry, legacy-hunting, deception, violence, back-biting, etc., are always there in human nature. Every character and every episode is relevant to our day to day activities in India. If we first take up the theme of the first deadly sin called the greed as is seen in the character of Duke Frederick, the usurping ruler of France who deposed his elder brother the Duke Senior and took every care to make his throne safe and free from any threat coming from any possible quarter. The likes of Duke Frederick are to be found in every time and clime, and in India there is no dearth of such crooked humans. That Duke Frederick is an arch-villain is proved beyond doubt from his cruel activities shown to his elder brother, Duke the Senior, the latter's daughter, Rosalind, and even an innocent and tortured soul, Orlando. Duke Frederick usurps the throne of France from his brother and compels him to run away for fear of life, but he does not allow his niece, Rosalind, to go away with her father, because his 
daughter, Celia, is deeply attached to her cousin. Here we see two motives to be present in the character of Duke Frederick. His anger is directed to his brother, the innocent Senior Duke and his affection to his daughter compels him to retain her in his palace.

Duke Frederick is, no doubt, a villain and his villainy grows gradually and rapidly until he experiences an epiphany. In his encounter with a hermit in the Forest of Arden where he goes in search of his run-away daughter. The human fate of sin and expiation is very much noticeable in the character of Duke Frederick. His villainy grows and grows until it can grow. Such epiphanies were experienced when the PrinceGoutama ofKapilavastu (of Nepal) underwent a tremendous psychological change on seeing an old man walking along the road at night leaning with great difficulty upon a walking-stick; and Ashoka, a great Indian king, feeling the same mental turn-about on seeing heaps of maimed bodies of slain soldiers in the field of battle after his victory in Kalinga. Such incidences are scattered thickly and profusely on the pages of the history of India. This proves that villainy and wickedness is a permanent negative human quality that takes various shapes and forms depending upon the variety of time and place, but it is there present all over the world not excepting India.

Howevermuch we may pride in being Indians, the residents of a country of rich culture in the past and the native land of such eminent persons as Valmiki, Veda Vyas, Tagore, Vivekananda and others, there invariably are petty local villains in every pocket of the country. These pettygoons usurp others' land, pollute human nature by seducing the innocent members of the fair sex and exploiting the weaker sections of the people, the women and the children in particular. The same policy of the dominance of the strong over the weak is active everywhere. Duke the Senior is deposed because he is weak, good and innocent; Rosalind is not allowed to go with her father because Duke Frederick is strong enough to make his order prevail; Duke Frederick is in a position to order Oliver de Boys to bring Orlando to his presence failing which Oliver's property would be confiscated and his residence gutted. In utter fear for his life and in order to save himself from the ire of Duke Frederick, Oliver has to undertake his long and uncertain journey to the Forest of Arden not knowing the fate of his mission. Oliver, thus, is also a helpless victim of Duke Frederick's cruelty and anger as is his brother, Orlando and even the former ruler of the land, Duke the Senior.

Tyranny is in another form is to be discerned in the character of Oliver de Boys whose wickedness is of a lesser kind and of lesser dimension because he is merely the son of a regional lord and not a national bully like Duke Frederick. His wickedness is directed to his younger brother, Orlando, who was so long too young to realise his deprivation and now that he has become wiser he raises his voice against the tyranny of his brother. The long suppression of his goodness has exploded like a volcano and he pounces upon Oliver forgetting the human decency of his loyalty to him and caring little to the age-old sense of decency shown to an elder sibling. Orlando is so angry that he would kill his brother and if it were not for Adam, the loyal servant of the family, to intervene in the family feud, Oliver could have been murdered by Orlando. But when Orlando comes to know that Oliver has planned his murder by setting his room on fire, he has to run away in the direction of the Forest of Arden to defend against the cruelty of his brother.

The Forest of Arden stands as an anti-type of the royal palace now under the command of Duke Frederick. The difference between the two places -the court and the forest - is well sounded in the words of the Duke Senior who says that he now is in perfect bliss in the lap of Nature far away from the hub of conspiracy seething in the ducal palace in the capital of the country. According to him, birds and animals are better than humans and the rural rustics are happier than the residents of the cities and towns, a view sounded in the poems belonging to the Lyrical Ballads composed by the Romantic stalwart William Wordsworth and also supported by the rustic characters of the Victorian novels written by Thomas Hardy. The burgeoning of innocence and peace in the lap of Nature against that of villainy and wickedness in the heart of politics in the royal palaces is evident in the contrast of the actions taking place in the court and the Forest of Arden.

Love is another strong human emotion running with the passage of time not depending upon the variation of time and place. Shakespeare is believed to have realised the great potentiality of the human emotion called love and its strong power exerted on an adult human being. It was he, who expounded and popularised the dictum called the love-at-first-sight and he was not wrong for certain. Both Rosalind and Orlando were the victims of this love-at-firstsight. Rosalind became a great sympathiser of Orlando because he was also, like her, a helpless victim of the ways of the big bad world. She was separated from her father after his dethronement and Orlando was deprived of his proper upbringing by his brother who was entrusted by his dead father to impart proper education to the youngest member of the family. What Duke Frederick did to his brother and his niece was also done by Oliver to his younger brother. But love seemed to lift the victims of 
misfortunes from the abyss of suffering and death. The love between Orlando and Rosalind ultimately flourish after going through so many hurdles. Travelling through many difficult terrain, the ardent lovers were ultimately united in the bond of marriage to live happily after. Not only they got the pleasure of love, their former happier state was also restored to each of them. At the end Rosalind was destined to return from the Forest of Arden to the royal palace, her rightful abode and Orlando also returned to his estate after his brother, Oliver having gone a change of heart after his brother's nobility was shown in the way Orlando saved Oliver from being devoured by a lioness, which Orlando killed with his sheer physical prowess. Like the love flowering between Orlando and Rosalind, that between Oliver and Celia was also a case of love-at-first-sight. Oliver was sent by Orlando to Rosalind in her cottage with the message that the latter was not in a position to come to her to do his duty of an ardent lover as he was attacked and wounded by a lioness in the forest, but on reaching there he found Celia, not Rosalind, with whom he fell in love-at-first-sight.

This variety of love called the love-at-first-sight also is active in the pair of Phebe and Silvius, the shepherd and the shepherdess living in the remote areas of the countryside at the fringe of the Forest of Arden. Phebe, who was reluctant to relent to the advances of Silvius, fell instantly in love with Ganymede not knowing that he was, in fact, Rosalind, a girl, disguised as a poor shepherd. The same theory of love-at-first-sight is also operative in the simple country folk, who are neither the members of a royal family like Rosalind nor a lord like Oliver and Orlando or others. It is the love between simple rustic people living in the midst of Nature and not in the middle of the turmoil of petty politics and the luxury of living.

Love is not the monopoly of the rich and the refined section of the society. Even lowly people are also equally bitten by the love-bug and pierced by the arrow of Cupid, the god of love. Touchstone and Audrey are the victims or rather the beneficiaries of this type of violent love. Social position does not become a bar in the case of these two lovers. Love, sometimes, is entailed with other consideration. Audrey, the poor country wench, harbours the hope of making it to the royal palace with her marriage with the court-jester.

It is true that Shakespeare romanticised the human emotion called love, but the originality of it is active for ever and for ever. A few years back, a prince in the royal palace of Kathmandu, the capital of Nepal, a neighbouring country of India, opened fire upon his kinsman, because they were opposed to his marriage with an Indian film-star. It was perhaps the most violent love come to light in the recent years. This also shows that Shakespeare was right in establishing the potency of love over other emotions working in the human personality.

The genocide occurring in the royal palace of Nepal was also a reflection of such love affairs taking place at different places in the plain constituting the major part of India. Many such cases of violent love resulting in tragedies are reported everyday in the newspapers. There is such proliferation in the number of such violence committed in the name of love that we have become habituated to such news and do not seem to give much emphasis on such matters. The plethora of the incidence has taken away the terror of such news items.

Shakespeare is famous for popularising the dramatic device called the mistaken identities. In his comedies, as also in his tragedies, there are cases of impersonation. People assume disguise to save themselves from misfortunes doggedly pursuing them. In 'AS You Like It', Rosalind and Celia assume the disguise of a poor shepherd, Ganymede, and his sister, Amelia, respectively in order to defend themselves from any harassment that might befall on them while their stay outdoor and in the perilous terrain of the big, bad world. That their plan was fool-proof is borne out by the fact that they never face any eve-teasing while their stay in the forest. Here the mistaken identity is a means to their end.

Though our present-day India and Shakespeare's England are more than three centuries apart, there are many things common between the two ages. Pride of power, suppression of the poor, exploitation of the weak, legacy-hunting, conspiracy in the seat of power, etc., are always there, be it England or India or Italy or France or any other remote part of the world. The same positive and negative traits of human character exist with some regional varieties and colours. Today we live in free India. There are no British colonisers to exploit or bully us. But the place of the tyrants has now been taken by our native counterpart who are no less ferocious than the foreign colonisers. The difference of wealth among the citizens of the country has widened after independence. The poor has become the poorer and the rich, richer. The net result of this is a undercurrent of public discontent. The two countries and the two ages of time - three centuries apart are not much different.

Shakespeare's another Romantic Comedy, 'Twelfth Night' (sub-titled 'What You Will') has also much similarities with India's modern times. There are some people who are devoid of any romantic feeling. Many of them are engaged in the politics of the country. They divert their energy not to the levity of youth, but to the pursuit of their financial ambition. Some unworthy 
may now be found cosily ensconced in the seats of power. Such power-hungry people have encroached the places of the tyrant rulers that ruled India in the past. A few of them are on the hot seat administration, but their minds are elsewhere. In Shakespeare's 'Twelfth Night Duke' Orsino is a sentimental lover who is not as interested in the administration of his country as he is in his personal interest in Olivia, the beautiful Countess and his neighbour. He cannot forget her. The more his proposal of love is spurned, the more it seems to grow. Some lovers are always shy and they do not possess to make the frank declaration of their emotion to their lover. Duke Orsino sends emissaries to Olivia one after another but he never approaches her personally. When he sends his page, Viola disguised as a male servant, the matter gets more complicated than it was before. Olivia falls in love-at-firstsight with the Duke's emissary not knowing that the emissary in fact is a girl and not a young man as she had thought her to be. Such cases of mistaken identity occur in every country and every age. It was easier for Shakespeare to pass off young girls as boys because English girls are not that buxom like their Indian counterparts. In Shakespeare's 'The Merchant of Venice', Portia, wife of Bassanio, assumes the disguise of a clerk of a Lawyer and saves Antonio, her husband's friend, from the clutches of blood-thirsty Shylock, who was hell-bent to cut off the pound of flesh from near the heart of Antonio. The eternal conflict between the good and the bad here exemplified by Antonio and Bassanio on the one hand and Shylock on the other may also be found in greater degree in the present Indian scenario. Rather, the present Indian situation is worse than that of England, France, Italy, Scotland, or any other country in which the greatest poet and the dramatist had set his plays more than three centuries ago.

Apart from the comedies of Shakespeare, and his tragedies also have much elements in common with present-day Indian situation. Now we see many politicians, having gathered experiences in one camp suddenly switches his/her loyalty to another camp and if it becomes inconvenient for him/her to gain much prominence, he/she returns to his/her former camp where he is hailed with much warmth. Back-biting and mud-slinging have increased manifold since the age of Shakespeare. In Shakespeare's 'Macbeth', it is King Duncan's trusted kinsman and loyal general who killed him in his own palace of Inverness. Evil grows very fast and when it cannot grow any further it is obliterated by another evil. All evils are destroyed by the intervention of the good. Macduff's sense of revenge overcame the growth of evil personified by Macbeth. If we subtract the supernatural elements and the royalty from the dramatic philosophy of
Shakespeare and delete the distance between England and India, we will see a place without name and time where there is only the perpetual tug-of-war between the good and evil. The tradition goes on the same.

\section{CONCLUSION}

Human behaviour does not change much with the passage of time and in different countries. Our seven deadly sins act in every human being. Power corrupts and absolute power corrupts absolutely. When there was monarchy, the proud rulers exploited their subjects and the human rights of the people were utterly ignored. When monarchy was gone and democracy was established, the master classes took command of the administration and they also suppressed any rebellion against their tyrannical rule. They only pampered privileged few, but the majority of the people became the helpless victims of the tyrants' misrule. But, in spite of this tyranny of the rich and the high-ups over the poor and the lowly could never destroy the basic principles of life. Love, charity, forgiveness, friendship, fellow-feeling, etc. remained unchanged in spite of the change of time and clime. Shakespeare, the greatest visionary of all times, has showcased this philosophy of humanity in his 37 plays - tragedies, comedies and histories as also his 52 sonnets and two long poems. Though written more than three centuries ago and in a country which was then at the centre of civilization, Shakespeare's vision of humanity is relevant to all countries and to all ages. India, a former colony of British dominion, amply comes under the holistic far-sight of Shakespeare. Evil grows gradually and when it reaches its peak, it is destroyed and peace and justice prevail.

\section{ACKNOWLEDGEMENT}

For the writing of this article the writer is highly indebted to Mr. Golam Mursid Khan who is an authority in Shakespearean literature and has gathered vast knowledge of the history of both England and India. Mr. Khan has provided the writer with necessary information from Shakespeare's plays such as 'AS You Like It', 'Twelfth Night', 'Macbeth', 'The Merchant of Venice', etc.

\section{REFERENCES}

[1] Shakespeare in India, K. R. Srinivasa Iyengar, India Literature, Sahitya Akademi (1964)

[2] Nagarajan,S., and S.Viswanathan, eds. Shakespeare in India, Delhi: Oxford University Press, 1987

[3] Different Shakespeare: the Bard in Colonial/Postcolonial India, Shakespeare: Varied Perspectives ed. Vikram Chopra, Delhi: B.R.Publications, 1996

[4] Dolan, Frances E. "Introduction" in Shakespeare, As You Like It. New York: Penguin Books, 2000 